JLARC 4 (2010) 28-42 28

\title{
COMMENTARY AND TRANSLATION IN SYRIAC ARISTOTELIAN SCHOLARSHIP: SERGIUS TO BAGHDAD ${ }^{1}$
}

\author{
John W.Watt (WattJ@cardiff.ac.uk)
}

\begin{abstract}
This article considers the relationship between the composition in Syriac of commentaries on Aristotle and the translation of his treatises from the time of Sergius of Reshaina through to the Baghdad scholars of the $8^{\text {th }}-10^{\text {th }}$ centuries. Surveying the work particularly of Sergius, the scholarly translators of Qenneshre, and the interests of Patriarch Timothy I as evidenced in his letters, it argues that the translation activity up to the $8^{\text {th }}$ century must be seen within the context of a school tradition in which the Syriac text of Aristotle was read in association with a written or oral commentary, or with the Greek text, or both. An appreciation of the link between commentary and translation, as also Syriac and Greek, in Graeco-Syriac Aristotelian scholarship of the $6^{\text {th }}-8^{\text {th }}$ centuries enables a better understanding of its relationship to the Syro-Arabic Aristotelian scholarship of Abbasid Baghdad.
\end{abstract}

\section{Sergius}

Sergius of Reshaina (d. 536) is widely recognised as the pioneer who first wrote on Aristotelian philosophy in Syriac. A student in the school of Ammonius at Alexandria and later a physician at Reshaina, he also greatly admired the writings of Galen and rendered many of them into Syriac. His most important treatise is his commentary on the Categories of Aristotle (or rather, the larger of his two commentaries on the Categories) - important in the sense that it was the starting point of the embedding of Aristotle's thought, especially his logic, in the intellectual culture of the Near East, ${ }^{2}$ a movement memorably encapsulated in Max Meyerhof's felicitous title to his famous essay Von Alexandrien nach Baghdad. While the hypothesis espoused by Meyerhof on the authority of al-Fārābi $\overline{1}^{3}$ of a migration of a single identifiable

\footnotetext{
${ }^{1}$ Abbreviations: $\mathrm{CAG}=$ Commentaria in Aristotelem Graeca; CSCO $=$ Corpus Scriptorum Christianorum Orientalium. An earlier form of this article was presented at the Symposium Syriacum, Granada, September 2008.

${ }^{2}$ On Sergius, see especially H. Hugonnard-Roche, La logique d'Aristote du grec au syriaque [collected articles 1987-2004], Textes et Traditions 9 (Paris, 2004), chapters VI-IX (pp. 123-231). Chapters VIII-IX (pp. 165-231) consist of introductions to and translations of (respectively) the Prologue and Book One of the larger commentary on the Categories; the commentary contains seven books. The text remains unedited; I quote from the oldest manuscript, British Library Add. 14,658 (hereafter simply Add. 14,658).

${ }^{3}$ M. Meyerhof, "Von Alexandrien nach Bagdad," Sitzungsberichte der preussischen Akademie der Wissenschaften, phil.-hist. Klasse 23 (1930), pp. 389-429. The text of al-Fārābī is in Ibn Abī

John W. Watt, "Commentary and Translation in Syriac Aristotelian Scholarship: Sergius to Baghdad," in: Journal for Late Antique Religion and Culture 4 (2010) 28-42; ISSN: 1754-517X; Website: http://www.cardiff.ac.uk/clarc/jlarc
} 
scholarly institution from Alexandria (via Antioch) to Baghdad is now held to be untenable, ${ }^{4}$ the phrase nevertheless still serves as an appropriate symbol of that process. When it reached Baghdad it embraced both Syriac and Arabic scholars, and on the Arabic side it extended from there both eastward and westward. The further development, though primarily Arabic, included both Hebrew and Syriac scholars, among the latter the most prominent being Bar Hebraeus. The climax of the Syriac contribution, however, was the work of the Syro-Arabic scholars of the Baghdad school of philosophy of Abū Bišr Mattā. Its alumni included Yahyā ibn 'Adī and Ibn Zur'a, but its most famous member was the Muslim al-Fārābī.

Sergius is the earliest discernible link between philosophy in Alexandria and the Semitic-speaking lands of Syria and Mesopotamia. Like the commentaries of the Greek Alexandrians, his commentary on the Categories includes an introduction to philosophy in general and to the writings of Aristotle as a whole and is conceived as the first in a series of commentaries on the logical pragmateia of Aristotle, what we term the Organon, to be followed by others on the entire school corpus of the philosopher. It was certainly Sergius' expressed intention to treat

"the aim of each one of the [logical] treatises, beginning the chain with that $O n$ Categories and similarly treating each one of them in the same way ... then to go on to his other treatises, those on the parts of practical (philosophy), then physics and mathematics, and finally those called theological.",

Whether any of the others were ever written is unknown, but Sergius certainly did not consider the Categories to be the only work of Aristotle worth studying, and the designation of the work (the original title of which is unknown) by one or more copyists, On the Aim of all the Writings of Aristotle, reflects its nature which, like the Greek commentaries, deals with some of the standard preliminary questions posed at the start of the entire curriculum.

I wish to draw attention here, however, not to the absence from his extant output of works which we know he at least intended to write, but to the absence of one of which we have no evidence that he intended to write, namely, a Syriac translation of the Categories itself. The early Syriac translation of that treatise of Aristotle in the same British Library manuscript (Add. 14,658) in which Sergius' commentary is preserved was of course for long assumed to be by Sergius, but that has now been shown by Henri Hugonnard-Roche to be untenable. ${ }^{6}$ If therefore Sergius did not make a translation of the Categories, although he made many other translations, we may well ask, "Why not?"

Ușaibi'a, ed. A. Müller, 'Uyūn al-anbā' fì țabaqāt al-aṭibbā' II (Cairo-Königsberg, 1882-1884), pp. 134-35; English translation in F. Rosenthal, The Classical Heritage in Islam (London, 1975), pp. $50-51$.

${ }^{4}$ Confidence in the historical veracity of al-Fārābī's account started to crumble with the article of G. Strohmaier, "Von Alexandrien nach Bagdad - eine fiktive Schultradition," in J. Wiesner (ed.), Aristoteles: Werk und Wirkung. Paul Moraux gewidmet II (Berlin, 1987), pp. 380-89.

5 Add. 14,658, fol. 3rb. Cf. J.W. Watt, "Al-Fārābī and the History of the Syriac Organon," in G. A. Kiraz (ed.), Malphono w-Rabo d-Malphone. Studies in Honor of Sebastian P. Brock (Piscataway, NJ, 2008), pp. 703-31 at pp. 718-20; reprinted separately with Addenda and Corrigenda in Analecta Gorgiana 129 (Piscataway, NJ, 2009).

${ }^{6}$ Hugonnard-Roche, La logique, p. 23-37.

John W. Watt, "Commentary and Translation in Syriac Aristotelian Scholarship: Sergius to Baghdad," in: Journal for Late Antique Religion and Culture 4 (2010) 28-42; ISSN: 1754-517X; Website: http://www.cardiff.ac.uk/clarc/jlarc 
It would seem natural to suppose that if Sergius wrote a Syriac commentary on the Categories, he would also have considered it desirable or necessary for his readers to have access to the work of Aristotle in Syriac. In principle, therefore, we appear to be faced with a number of possibilities: Sergius did make a translation of the Categories, but it is no longer extant; or he assumed his readers could refer to the old Anonymous previously often supposed to be by him; or he assumed his readers would refer to the Greek text of the Categories; or he did not consider that his readers would need or wish to refer to the text of Aristotle himself. Let us consider each of these, beginning with the last of them.

Sergius' commentary has much in common with those of Ammonius and Philoponus. These Greek commentaries were not conceived to be read in isolation from the text of Aristotle, but in conjunction with it. A recent analysis of Alexandrian commentaries on Plato and Aristotle has distinguished two types, one the product of teaching in a classroom setting, the other separate from such a setting and offering an extensive amount of literary material in an effort to present a comprehensive account of a philosophical system. ${ }^{7}$ In both types the commentator assumes that the listener or reader has available the text of the ancient philosopher (Plato or Aristotle), in the case of the former that the audience has the relevant Platonic or Aristotelian text in front of them, but not necessarily anything additional. It was certainly not envisaged by any of the Greek commentators that their work should be read in ignorance of the text which they were expounding.

Sergius repeatedly states that his aim is to expound Aristotle's teaching concisely ( $b-p \bar{a} s \bar{\imath} q \bar{a} t \bar{a}$, literally "in cuttings"), which clearly puts it into the second group of those differentiated (from a different point of view from that immediately above) by Simplicius, those whose intention was to "reveal ( $\alpha \pi \circ \kappa \alpha \lambda u ́ \pi \tau \varepsilon \imath v)$ the thoughts

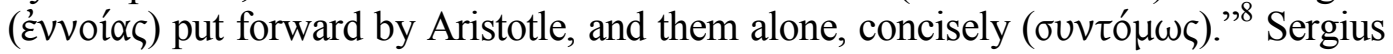
did not proceed, like Porphyry, by means of questions and answers, so it is not necessary to assume that he was tightly tied to one particular model among the Greek commentators, but if his commentary was written in the knowledge that his readers could not access the text of Aristotle himself, then he was doing something very different from his Greek models. Explaining, for example, (in the manner of the Greek commentators) why Aristotle used obscure language is surely quite beside the point if Sergius himself did not employ the same obscurity and his readers were never expected to consult the text of the Philosopher himself. If such a situation

${ }^{7}$ Cf. E. Watts, "Translating the Personal Aspect of Late Platonism in the Commentary Tradition," in J. Lössl and J.W. Watt (eds), Interpreting the Bible and Aristotle in Late Antiquity. The Alexandrian Commentary Tradition between Rome and Baghdad (forthcoming). As an example of the former type Watts refers to Olympiodorus' Commentary on Plato's Gorgias, of the latter Simplicius' Commentary on Aristotle's Physics. In the same general vein J. Barnes, "David and the Greek Tradition," in V. Calzolari and J. Barnes (eds), L'œuvre de David l'Invincible et la transmission de la pensée grecque dans la tradition arménienne et syriaque (Leiden, 2009), p. 5 distinguishes between commentaries "ballasted with scholarly arcana" and those "for the student market".

${ }^{8}$ Simplicius, in Cat. p. 1, 10-12, ed. K. Kalbfleisch, CAG VIII (Berlin, 1907). Cf. e.g. from Sergius: "for in this way all of his doctrine which is in this book (sc. the Categories) will be visible in cuttings' to those who read (sc. my exposition)" (Add. 14,658, fol. 7rb). Barnes (as in preceding note) notes that a commentary "feeds off another text, and it will scarcely be understood save in the company of that text."

${ }^{9}$ Add. 14,658, fol. 3rb-4rb. Cf. Ammonius, in Cat. p. 7, 7-14, ed. A. Busse, CAG IV 4 (Berlin, 1895); also Philoponus, in Cat. p. 6, 22-28, ed. A. Busse, CAG XIII 1 (Berlin, 1898).

John W. Watt, "Commentary and Translation in Syriac Aristotelian Scholarship: Sergius to Baghdad," in: Journal for Late Antique Religion and Culture 4 (2010) 28-42; ISSN: 1754-517X; Website: http://www.cardiff.ac.uk/clarc/jlarc 
could have been envisaged by Sergius, he could surely not have imagined it as anything other than 'second best' - which still leaves unexplained why he would not have rectified it by providing a translation. ${ }^{10}$

In the Latin-speaking area Boethius both wrote expositions of some of Aristotle's logical works (Categories and De Interpretatione) and translated the whole Organon into Latin. Roughly contemporary in the Syriac-speaking world we can see the beginning of the West Syrian tradition of biblical commentary in the writings of Philoxenus of Mabbug, who, as is well known, was also greatly interested in biblical translation and commissioned a new Syriac version of the New Testament as a result of his experience as a theological commentator. ${ }^{11}$ Both Boethius and Philoxenus assumed that their commentaries would be read in association with the ancient text, and that in their linguistic circumstances this necessitated close attention to the process of translation. Sergius himself was a prolific translator: his attested translations include around thirty treatises of Galen, five treatises of the Corpus Dionysiacum, Pseudo-Aristotle De mundo, and Alexander of Aphrodisias' On the Principles of the Universe. ${ }^{12}$

Turning now to the other possibilities, it may be that the old anonymous version already existed and Sergius intended his readers to make use of it. This solution is very unlikely, however, for the same reason that he is now not thought to have been its author, namely, the difference in terminology between the version and his commentary. If Sergius had intended his commentary to be read with that translation, he would surely have made an effort to harmonise his terminology with it, or at least to explain how his preferred terminology differed from that of the translation. Equally implausible is the idea that he did make a translation but it is lost, for his commentary survives in the same manuscript as the old anonymous translation. If Sergius had issued a translation with his commentary, it is hard to believe that the two would not have survived together at least long enough for both to be in a seventh century manuscript (BL Add. 14,658), and that his translation would have been replaced in it by one from another hand. That leaves us with the final possibility: he expected his readers - or at any rate those of them who were not satisfied with what I described above as "second best" - to refer to the Categories (and by extension the rest of the curriculum of Aristotle's autoprosopa) in Greek ${ }^{13}$

Unlike the other possibilities, this one is by no means improbable. From the stylised rhetorical prologue to the work we know of one reader, namely its (apparent)

${ }^{10}$ Cf. Hugonnard-Roche, La logique, p. 81: "il est remarquable que Sergius ait rédigé un exposé touchant les Categories plutôt qu' une traduction ..." An analogous, if not identical, issue arises in the Armenian Aristotelian tradition. There is an Armenian version of David's (or possibly Elias') Commentary on the Prior Analytics (in reality only on I 1-7), but apparently no evidence for an Armenian version of the Prior Analytics itself. The issue is not identical, because David's Armenian Commentary is a translation from Greek, while Sergius' is an original Syriac work. Nevertheless, it raises the question: if David's Commentary "feeds off another text, and [can] scarcely be understood save in the company of that text" (cf. above, n. 7), how could an Armenian reader understand it without an Armenian version of the Prior Analytics itself?

${ }^{11}$ A. de Halleux, Philoxène de Mabbog (Louvain, 1963), pp. 117-25.

${ }^{12} \mathrm{Cf}$. Hugonnard-Roche, La logique, pp. 125-31.

13 This conclusion has something in common with the view of Khalil Georr, Les Catégories d'Aristote dans leurs versions Syro-Arabes (Beirut, 1948), pp. 11-12, although Georr (surely incorrectly) took this "Greek period" of Syriac study of Aristotle back to the School of the Persians in Edessa.

John W. Watt, "Commentary and Translation in Syriac Aristotelian Scholarship: Sergius to Baghdad," in: Journal for Late Antique Religion and Culture 4 (2010) 28-42; ISSN: 1754-517X; Website: http://www.cardiff.ac.uk/clarc/jlarc 
addressee, Theodore, bishop of Karkh Juddan, but it was certainly not written for him alone; ${ }^{14}$ the prologue concludes with the remark that the treatise is written not only on account of pressure from Theodore, as he has previously said, but also because he believes that those who read them (i.e. Aristotle's writings) can gain thereby an excellent preparation for knowledge. ${ }^{15}$ Sergius and Theodore translated together some of the works of Galen, but while Sergius rendered the Greek into Syriac, Theodore's contribution was (according to Sergius) to correct his Syriac according to the stylistic requirements of the target language. ${ }^{16}$ We cannot be sure, therefore, that Theodore himself could read Greek, but we can be sure that in the area where Syriac was employed there were a great many bilinguals able (like Sergius himself) to do so. ${ }^{17}$ One recent study has proposed that Sergius himself was in fact more at home in Greek than in Syriac, another that the Syriac commentator and translator Probus may have been identical to the Greek theologian of that name. ${ }^{18}$ Whatever the case in these two instances, Greek-Syriac bilingualism was certainly a feature of the Syriac language area.

Despite this bilingualism, we must conclude that Sergius envisaged the most serious philosophical studies in the Syriac-speaking area to be confined to a linguistic elite, for clearly not all could read Greek. This conclusion need hardly be a cause of great surprise, for the study of Aristotelian philosophy was nothing if not an elite pursuit in itself, even among a purely Greek-speaking population. Sergius, however, did not apply this linguistic restriction to all Syriac "professionals". For Syriac medical practitioners he translated many works of Galen, and for those aspiring to the heights of Christian theology and spirituality he translated the Corpus Dionysiacum. ${ }^{19}$ For those wishing to learn about Aristotelian physics at a

\footnotetext{
${ }^{14}$ On the rhetorical prologue addressed to Theodore, cf. Hugonnard-Roche, La logique, pp. 16775. The literary device of introducing a treatise as the response to a request from a friend or superior is a standard one in Greek rhetorical theory. A similar case in Syriac contemporary with Sergius is the prologue of the so-called "Chronicle of Joshua the Stylite" (dated c. 506 A.D., addressed to an abbot named Sergius!). The historical reality of the request and the friend cannot therefore always be assumed without question. In the present case there is no need to doubt the reality of Theodore, but one should certainly not assume that the work was written for him alone, or only because he requested it (as the concluding remark from the prologue, cited immediately below, confirms). Cf. F. R. Trombley and J. W. Watt, The Chronicle of Pseudo-Joshua the Stylite, Translated Texts for Historians 32 (Liverpool, 2000), pp. xii-xiii, 1-7.

${ }^{15}$ Hugonnard-Roche, La logique, pp. 169-70.

${ }^{16}$ Cf. Hugonnard-Roche, La logique, p. 168.

${ }^{17}$ As Hugonnard-Roche, La logique, pp. 133-34 notes, in some of his works, including this commentary on the Categories, Sergius was clearly addressing a public "déjà frotté de culture grecque".

${ }^{18}$ E. Fiori, "Sergius of Reshaina and Dionysius: A Dialectical Fidelity," and S. Brock, "The Commentator Probus: Problems of Date and Identity," both in Lössl and Watt, Interpreting the Bible and Aristotle.

${ }^{19}$ Sergius' view was that without Aristotle's logic not only medicine and philosophy cannot be understood, but neither "can the true sense be uncovered of the divine Scriptures, wherein lies the hope of our salvation - unless it should be that someone receives divine ability thanks to the exalted nature of his way of life, with the result that he has no need for human instruction" (Add. 14,658, fols. 60vb-61ra). With those who "receive divine ability thanks to the exalted nature of their way of life" Sergius was doubtless referring to Christian holy men; Syriac-speakers among such holy men could presumably make use of these and other works (the Bible of course, and also spiritual works such as those of Evagrius, on whom see below) without the "human instruction" of Aristotle's philosophy.
}

John W. Watt, "Commentary and Translation in Syriac Aristotelian Scholarship: Sergius to Baghdad," in: Journal for Late Antique Religion and Culture 4 (2010) 28-42; ISSN: 1754-517X; Website: http://www.cardiff.ac.uk/clarc/jlarc 
level "below" that of the treatises in the main cursus, he translated the (pseudoAristotelian) De mundo and (with extensive modifications) Alexander's On the Principles of the Universe. ${ }^{20}$ He recognised, therefore, that those who could not cope with the Greek could still learn something of Aristotelian philosophy from translations. It does appear, however, that he considered anyone who wished to engage in philosophy in a manner comparable to that required of the students who read the school works (akroamatika) ${ }^{21}$ would need to be able to read Aristotle in the original. There was no contradiction in composing a commentary in Syriac for native Syriac speakers while requiring them to consult Aristotle in Greek, so long as this option was available to them. ${ }^{22}$ At the time of Sergius' writing it is quite likely that no other commentaries from the school of Ammonius were known in Syria or Mesoptamia, ${ }^{23}$ but in due course some of them did become known in Hellenophile circles (see below).

Of the two kinds of commentary noted above, the "classroom exposition" of a "set text" and the extensive literary presentation of a philosophical system, Sergius' commentary is undoubtedly related to the former. He himself had been a student in Alexandria, clearly in the School of Ammonius. It is not unreasonable to suppose, therefore, that he would have considered his commentary suitable material for school instruction, together with the text of Aristotle, whether or not he consciously designed it as such. Not everyone, however, need have accepted his linguistic restriction. Once teaching about Aristotle came into being in Syriac, demand for a Syriac translation could soon emerge from those whose Greek was non-existent or inadequate to the challenge of Aristotle's text. Although the early anonymous translation of the Categories differs in its rendering of technical terms from that of Sergius, it is still possible that it resulted from an interest in the work generated by the appearance of Sergius' commentary, or more generally by the emergence of

${ }^{20}$ On these two see recently: A. McCollum, "Sergius of Reshaina as Translator: The Case of the De Mundo," in Lössl and Watt, Interpreting the Bible and Aristotle; and E. Fiori, "L'épitomé syriaque du traité Sur les causes du tout d'Alexandre d'Aphrodise attribuée à Serge de Resh'aynā. Édition, traduction et index," and D. King, "Alexander of Aphrodisias' On the Principles of the Universe in a Syriac Adaptation," Le Muséon 123 (2010), pp. 125-56 and 157-89.

${ }^{21}$ On the distinction between popular or general works (exōterika) and the school works (akroamatika) "which have to be listened to attentively by one who is serious and in fact a genuine lover of philosophy," cf. e.g. Ammonius, in Cat. p. 4, 18-27.

${ }^{22}$ At the risk of proposing an anachronistic analogy, it may be suggested that it is not completely dissimilar to the requirement placed upon contemporary students of classics or theology (at least in Departments with rigorous language requirements) to read texts in ancient Greek, Latin or Hebrew while reading commentaries on them in their native (or another European) language. Of course, since European or American students are not bilingual in the sense being discussed here, the analogy is not perfect.

${ }^{23}$ Since Sergius was probably not a young man when he died in 536, Philoponus lived c. 490575 , and his commentaries on the Organon were written c. 512-520, it seems better to characterise Sergius as a fellow student with Philoponus of Ammonius, rather than a pupil of Philoponus. Since Ammonius' commentaries were edited by Philoponus, it is likely that at the time Sergius wrote his commentary those of Ammonius and Philoponus were known only to a few. In his sweeping assertions concerning the dependence of Sergius on Philoponus, Giuseppe Furlani, "Sul tratto di Sergio di Rêsh'aynâ circa le categorie," Revista trimestrale di studi filosofici 3 (1922), pp. 135-72, at p. 172 seems unaware of the conservatism uniting all the late antique Alexandrian commentators on Aristotle and the consequent strong family resemblance between all of them. Furlani's article gives a partial translation of (and also, it must be said, a partial insight into) Sergius' commentary.

John W. Watt, "Commentary and Translation in Syriac Aristotelian Scholarship: Sergius to Baghdad," in: Journal for Late Antique Religion and Culture 4 (2010) 28-42; ISSN: 1754-517X; Website: http://www.cardiff.ac.uk/clarc/jlarc 
teaching in Syriac about Aristotle to those who could not easily or at all cope with his Greek. In fact, however, translating Aristotle into generally comprehensible Syriac is just as demanding as teaching about him, or perhaps even more so. This is clear from the Anonymous of the Categories, which is often incomprehensible if read purely in 'normal' Syriac. Some of the problems stem from the translator's misunderstanding of the original - his knowledge of Greek was clearly inferior to Sergius' - but in other places Aristotle's meaning is difficult to discern even where the translation can be considered "correct", if the reader is dependent solely on the Syriac version. ${ }^{24}$ A Syriac reader who did not know and understand the Greek would therefore have required a commentary or a teacher to make sense of it. It would therefore not be surprising if, as seems likely (albeit not certain), Probus, the early Syriac commentator on the De interpretatione and the Prior Analytics to I 7, was also the translator of the early Syriac version of the former (and possibly, though less likely, of the latter). ${ }^{25}$ At a later date George, bishop of the Arabs, issued his translations of Categories, De interpretatione, and the complete Prior Analytics together with commentaries. It is therefore not credible that Syriac translations of Aristotle were ever meant to "stand alone", in isolation from the Greek, or from a commentary or from a teacher. Someone who did not know Greek would need a teacher or commentary to make sense of them, while the bilingual reader could use them as the modern student can use the right-hand pages of the Loeb or Budé editions to help him understand the original. ${ }^{26}$

"Syriac Aristotelianism" cannot therefore be treated as a monolithic entity. In some cases instruction could have been given on the basis of the Greek text of Aristotle, in others to monolingual students on the basis of a Syriac translation alone, whose meaning was explicated by a teacher who understood the Greek from which it came, and in yet others to students equipped with both, like a Syriac "Loeb"or "Budé". Only those proficient in Greek could make use of the Greek commentators without a translation or a teacher proficient in Greek. Neither can we assume that all engagement with Aristotle was based on total adherence to the Alexandrian curriculum. Another tradition with old roots in the Graeco-Roman world envisaged a course on logic comprising not the whole Organon according to the Alexandrian school, but the Categories, De Interpretatione, and Prior Analytics I 1-7 (i.e. predication, propositions, and assertoric syllogisms), ${ }^{27}$ and this

\footnotetext{
${ }^{24}$ As an example the use of 'aynā may be mentioned to render the Aristotelian "qualification" (poios). See D. King, The Earliest Syriac Translation of Aristotle's Categories, Aristoteles SemiticoLatinus 21 (Leiden, 2010), pp. 189-90, 221-23. King's chapter (pp. 39-79) on the translation techniques of the Anonymous provides further examples not only of the problems faced by the translator, but also of the difficulties faced by any reader of this translation without the help of a commentary or teacher, or of course the original Greek.

${ }^{25}$ Cf. S. Brock, "The Syriac Commentary Tradition," in Ch. Burnett (ed.), Glosses and Commentaries on Aristotelian Logical Texts: The Syriac, Arabic and Medieval Latin Traditions, Warburg Institute Surveys and Texts XXIII (London, 1993), pp. 3-18, at pp. 13-14; Hugonnard-Roche, La logique, pp. 57-67.

${ }^{26}$ It is presumably because Ibn Suwār was unaware of this that he was so critical of the Syriac translations of Athanasius of Balad (on which see below).

${ }^{27}$ This tradition is probably as old as the second century (Apuleius); cf. Watt, "The Syriac Organon," pp. 704-6, 715-17. The manuscripts of Greek commentators recognise a break at the end of I 7 ("end of the first part on the three figures") and the start of a new section at I 8 ("beginning of the mixed"). Cf. Philoponus, in Analytica Priora pp. 118-19, ed. M. Wallies, CAG XIII 2 (Berlin,

John W. Watt, "Commentary and Translation in Syriac Aristotelian Scholarship: Sergius to Baghdad," in: Journal for Late Antique Religion and Culture 4 (2010) 28-42; ISSN: 1754-517X; Website: http://www.cardiff.ac.uk/clarc/jlarc
} 
tradition was presumably responsible for the appearance in Syriac of the translation and commentary on Prior Analytics ending at I 7, as also a number of Syriac manuscripts containing to a greater or lesser degree the Syriac text of Aristotle corresponding to this curriculum without anything from the rest of the full Organon. ${ }^{28}$ Al-Färābī's assertion that the Organon beyond the assertoric figures was not studied with a teacher in a period prior to the coming of Islam has been considered to reflect "the Syriac tradition" up to the late eighth century, ${ }^{29}$ but this is not in accord with the Syriac evidence as a whole, and al-Fārābī's assertion (which in fact is made with reference to Alexandria, not Syrians) is more likely to have been motivated by a desire to affect the circumstances of his own time than to reflect any knowledge of earlier Syriac school practice. ${ }^{30}$

Although the only works on the Organon we possess from Sergius' hand are the two treatises on the Categories, his own view of Aristotle's writings accords with that of his Alexandrian teachers. As in the Categories commentary of Philoponus, Sergius compares Aristotle's procedure to that of an architect building a house, whose thinking begins with the roof and ends with the foundations, but whose activity begins with the foundations and ends with the roof. Correspondingly Aristotle's thinking on the "discriminating instrument" of logic began with de-

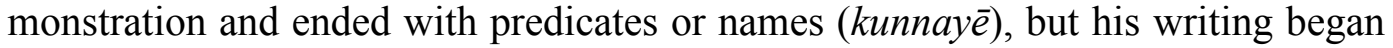
with the Categories and ended with the Posterior Analytics (alternatively named Apodeictics), after which he gave instruction "about everything useful to it in any way" (Topics, Sophistical Refutations, and possibly Rhetoric). ${ }^{31}$ Those Syrians who followed Sergius' thinking, or that of any of the Greek commentators, would not have been satisfied with the "short curriculum" which ended at Prior Analytics I 7, but would have seen the Posterior Analytics as the capstone of the Organon with the preceding three books as essential preliminaries and the remainder (two, three or four depending on the inclusion or otherwise of the Rhetoric and the Poetics) as optional additions. This is the basis of the "four plus four" division mentioned in later Syriac and Arabic writers and the evaluation of the relative importance of each book in the Baghdad school of Abū Bišr Mattā, which was passed on to al-Fārābīi. ${ }^{32}$

1905). The full Organon probably dates from the fourth century; I. Hadot, Simplicius. Commentaire sur les Catégories, fasc. 1, Philosophia Antiqua 50 (Leiden, 1990), pp. 82-83.

${ }^{28}$ Cf. Hugonnard-Roche, La logique, pp. 91-97. It is doubtful, however, whether the old manuscript Add. 14,658 containing Sergius' commentary on the Categories should be placed in this group, as the Categories is the only treatise of Aristotle which figures among the works within it. Cf. Watt, "The Syriac Organon," p. 723, n. 66; and D. King, "Origenism in Sixth Century Syria. The Case of a Syriac Manuscript of the Pagan Philosophers," in A. Fürst (ed.), Origenes und seine Bedeutung für die Theologie- und Geistesgeschichte Europas und des Vorderen Orients. Adamantiana: Texte und Studien zu Origenes und seinem Erbe I (Münster, 2011), forthcoming.

${ }^{29}$ D. Gutas, "The 'Alexandria to Baghdad' Complex of Narratives. A Contribution to the Study of Philosophical and Medical Historiography among the Arabs," Documenti e studi sulla tradizione filosofica medievale 10 (1999), pp. 155-93, at pp. 183-86.

${ }^{30}$ Cf. Watt, "The Syriac Organon," pp. 725-31.

31 Add. 14,658, fols. 2va-3rb; Furlani, "Sul tratto di Sergio," pp. 140-42; Watt, "The Syriac Organon," pp. 719-20. On the inclusion of the Rhetoric and Poetics within the Organon of the commentators, cf. Deborah L. Black, Logic and Aristotle's Rhetoric and Poetics in Medieval Arabic Philosophy, Islamic Philosophy and Theology VII (Leiden, 1990), pp. 31-36.

${ }^{32}$ Cf. Watt, "The Syriac Organon,” pp. 726-30.

John W. Watt, "Commentary and Translation in Syriac Aristotelian Scholarship: Sergius to Baghdad," in: Journal for Late Antique Religion and Culture 4 (2010) 28-42; ISSN: 1754-517X; Website: http://www.cardiff.ac.uk/clarc/jlarc 
It was noted above that Sergius' commentary is closely related to the type of "classroom exposition" of the Greek commentators, rather than the systematic exposition away from the presence of an audience. It is therefore natural to ask whether he envisaged a "classroom situation" in the Syriac-speaking world where Aristotelian philosophy could be taught, since we know of no school of philosophy there comparable to that at Alexandria. His (untitled) work known as the Memra on the Spiritual Life, originally an independent work but later placed by him as a prologue to his translation of Pseudo-Dionysius, points us in this direction. In it he considers a curriculum of knowledge in which are bound together the full range of Aristotelian philosophy in the Alexandrian interpretation (logic, physics, mathematics, metaphysics) and the Christian spirituality and theology of Evagrius of Pontus and Pseudo-Dionysius. ${ }^{33}$

This bold and original move can nevertheless be seen as related to his Alexandrian education, where the study of Aristotle was viewed as a preliminary to that of the "divine Plato": Sergius replaced the Neoplatonic theology and theurgy of his pagan lecturers with the Christian spirituality of Evagrius and the Christian Neoplatonism of Pseudo-Dionysius. ${ }^{34}$ The classroom in the Syriac-speaking world in which Sergius could have conceived instruction in this curriculum was therefore that of the monastic school. We do not know how many of these schools followed this model, but we do know of an influential one from which came many important figures in the West Syrian church who appear to have been formed by just such an education.

\section{Qenneshre}

At about the same time as Sergius was writing his commentary, around 530, John bar Aphtonia led the monks of the monastery of St. Thomas at Seleucia on the Orontes to a new foundation at Qenneshre on the Euphrates, on account of their opposition to the policies of Justinian. John came from a Hellenised family in Edessa and had been educated at St. Thomas, a celebrated centre of Greek education. Qenneshre therefore had both Greek and Syriac "in its genes" and the scholars associated with it as teachers or pupils were the visible seventh century successors of the Graeco-Syriac Aristotelianism inaugurated by Sergius. ${ }^{35}$ The commentaries

\footnotetext{
${ }^{33}$ Cf. my article "From Sergius to Mattā: Aristotle and Pseudo-Dionysius in Syriac Tradition," in Lössl and Watt, Interpreting the Bible and Aristotle in Late Antiquity. The memra is edited with a French translation by P. Sherwood, "Mimro de Serge de Rešayna sur la vie spirituelle," L'Orient syrien 5 (1960), pp. 433-57; 6 (1961), pp. 95-115, 121-56. The key passage is at $\S \S 79-81$ (vol. 6, pp. 122-25).

${ }^{34}$ Cf. I. Hadot, "Der fortlaufende philosophische Kommentar," in W. Geerlings and Ch. Schulze (eds), Der Kommentar in Antike und Mittelalter, Clavis Commentariorum Antiquitatis et Medii Aevi 2 (Leiden, 2002), pp.183-199: "Die Erklärung der Schrift des Aristoteles wird als Werk der Frömmigkeit aufgefaßt. Die Einstellung des neuplatonischen Exegeten gleicht somit der des christlichen Exegeten, der die Bibel erklärt" (p. 198). On the specific link made by Sergius between logic and the understanding of the Bible, see above, n. 19.

${ }^{35}$ Cf. my article "A Portrait of John bar Aphtonia, Founder of the Monastery of Qenneshre," in J. W. Drijvers and J. W. Watt (eds), Portraits of Spiritual Authority, Religions in the Graeco-Roman World 137 (Leiden, 1999), pp. 155-69. On Qenneshre as a "station stop" on the "journey from Al-

John W. Watt, "Commentary and Translation in Syriac Aristotelian Scholarship: Sergius to Baghdad," in: Journal for Late Antique Religion and Culture 4 (2010) 28-42; ISSN: 1754-517X; Website: http://www.cardiff.ac.uk/clarc/jlarc
} 
(mentioned above) of George, bishop of the Arabs, on the first three books of the Organon show not only that commentary remained important, but also that some of the Greek commentators were known in that milieu. ${ }^{36}$

But Qenneshre is especially significant in providing us with the earliest evidence of a complete Organon in Syriac (barring possibly the Rhetoric and Poetics). At Qenneshre they not only read the whole Organon in Greek, but also translated it. Athanasius of Balad (d. 687) translated, as far as we can tell for the first time, the complete Prior Analytics and the sequence from the Posterior Analytics to the Sophistical Refutations, Jacob of Edessa (d. 708) revised the old version of the Categories, and George (d. 724) produced revised versions of, as well as commentaries on, the Categories, De Interpretatione, and Prior Analytics. ${ }^{37}$ These men could read Aristotle in Greek (and of course not only Aristotle, but also the Greek Fathers), and no more needed a Syriac version than did Sergius. But presumably, a hundred years or more after his death, ${ }^{38}$ the circle of those who wished to read the Philosopher had grown significantly beyond those who could cope either sufficiently or at all with the Greek text. The mirror type of translation in vogue during the seventh century and adopted by these translators privileged the wording of a Greek text over the natural idiom of the Syriac. ${ }^{39}$ They were therefore by themselves even more incomprehensible to a student without Greek than the earlier more paraphrastic translations, but could be used by a teacher who himself knew the Greek as a basis for expounding Aristotle to Syriac-speaking students. The Greek remained the benchmark and the translations were always in principle subject to revision to make them better "mirrors". They were therefore to be read in association with commentary, either a written commentary or an oral exposition of a teacher (or both), or could be viewed by students who knew Greek as an entrée into the Greek text.

exandria to Baghdad", see further my article "Von Alexandrien nach Bagdad. Ein erneuter Besuch bei Max Meyerhof," in Fürst, Origenes und seine Bedeutung, forthcoming.

${ }^{36}$ Cf. G. Furlani, "La versione e il commento di Giorgio delle nazioni all' organo aristotelico," Studi italiani di filologia classica N.S. 3 (1923), pp. 305-33. Cf. also on Jacob of Edessa and the earlier Categories version, Hugonnard-Roche, La logique, pp. 43-55.

${ }^{37}$ Cf. S. Brock, "The Syriac Commentary Tradition," pp. 4-5; id., "Two Letters of the Patriarch Timothy from the late Eighth Century on Translations from Greek," Arabic Sciences and Philosophy 9 (1999), pp. 233-46, the references to Athanasius' translations of the Posterior Analytics and Topics at p. 238 (translation) with commentary pp. 245-46; Watt, "The Syriac Organon," pp. 707-12. Since Athanasius' translations of Gregory of Nazianzus and Pseudo-Dionysius were revisions of earlier translations (cf. Brock, "Two Letters," pp. 237, 242-44), we cannot exclude the possibility that the same applies to some or all of his Organon translations, but we have no evidence for such earlier translations. Athanasius' translation of Pseudo-Dionysius (not identifiable in the manuscripts, but possibly the initiation of work completed by Phocas, see Brock, ibid., p. 244) is a clear indication that Pseudo-Dionysius as well as Aristotle was read by (some at least) in Qenneshre. On the further association of the two through to the tenth century in Baghdad, see my "From Sergius to Mattã: Aristotle and Pseudo-Dionysius in Syriac Tradition."

${ }^{38}$ We do not know the date of Athanasius' lost translations of the four treatises of Aristotle in the Organon, but we do know the date of his surviving translation of the Eisagoge, namely 645. Cf. Hugonnard-Roche, La logique, p. 82.

${ }^{39}$ Some examples of Athanasius' fidelity to the Greek in his translation of the Eisagoge are given by Hugonnard-Roche, La logique, pp. 83-86.

${ }^{40}$ A parallel to the literal Greek-to-Syriac translations of theological and philosophical works can be found in the literal Latin-to-Greek translations of legal texts made for Greek-speaking students at

John W. Watt, "Commentary and Translation in Syriac Aristotelian Scholarship: Sergius to Baghdad," in: Journal for Late Antique Religion and Culture 4 (2010) 28-42; ISSN: 1754-517X; Website: http://www.cardiff.ac.uk/clarc/jlarc 


\section{Baghdad}

When we come to Baghdad in the late eighth century, we find the Greek text of Aristotle, the translations of Athanasius, and the works of the commentators all still associated with one another in the milieu of the East Syrian Patriarch. In 799 Timothy I in correspondence (letter 48) with Sergius, Metropolitan of Elam, about the sense of auletrides in Posterior Analytics I 13 (78b31) reveals that he has ascertained its meaning "from the translation which Athanasius made of the book of the Apodeictics from Greek to Syriac (in which) he wrote zammārātā ("women musicians') for auletrides ("women flutists")." In the Topics he also knows that the same translator "in each place puts zammārūtā for aulētridion but zammārātā for aulettrides." "41 Later in the letter he notes that only with difficulty could some "Greeks" (including the patriarch of the Melkites) understand the word "when we were translating the book of the Topics into Arabic from Syriac" and "the fact that they accepted zammārāta was from our happening upon it in the translation of Athanasius, or they accepted it on account of their own investigation." ${ }^{\prime 2}$

Timothy therefore probably had both Greek and Syriac texts of Aristotle at his disposal (the Posterior Analytics and Topics in the Syriac of Athanasius) and considered it natural to consult them both. ${ }^{43}$ In another letter to Sergius (letter 19) he noted that "the (Syriac) language is my own and is my home...but I studied foreign languages ... Greek and Arabic," "44 and while he had some knowledge of Greek it is clear from a letter to Pethion (letter 43) that he appreciated having Syriac translations of the Greek Fathers Gregory and Dionysius, including those made by Paul, Phocas, and Athanasius. ${ }^{45}$

the Law School of Beirut. The procedure at the Law School may well have been the inspiration for the parallel phenomenon of the treatment of Greek patristic and philosophical texts for the benefit of Syriac-speaking students. Cf. D. King, The Syriac Versions of the Writings of Cyril of Alexandria, CSCO 626, Subsidia 123 (Leuven, 2008), pp. 378-84.

${ }^{41}$ The letter is edited with a French translation in H. Pognon, Une version syriaque des aphorismes d'Hippocrate (Leipzig, 1903), the citations from p. XXI, 13 to p. XXII, 2 (text) and pp. XXIII to XXIV (translation). It is translated into English (using additional Syriac manuscripts) with a commentary by Brock, "Two Letters," the passage at p. 238 (translation) with commentary pp. 245-46. In the commentary (p. 245) Brock notes that aulètridion is an error for aulētiké (Topics I 10 [104a18 and 19]).

${ }^{42}$ Pognon, Une version syriaque, p. XXII, 21-26 (text), p. XXV (translation); Brock, "Two Letters," p. 239 (translation) and p. 246 (commentary).

${ }^{43}$ It is not impossible that 'in each place' (i.e. Post. An. $78 \mathrm{~b} 31$ and Top. 104a18 and 19) Timothy only read the Syriac which had a marginal note indicating the Greek, but given his study of Greek and his wish for some commentary or scholia on the Topics "whether in Syriac or not" (see below), access to a Greek text is much more probable.

${ }^{44}$ O. Braun, Timothei Patriarchae I: Epistulae, CSCO 74-75, Scriptores Syri 30-31 (Rome-ParisLeuven, 1914-1915), p. 127 (text), p. 85 (version). On the significance of this letter, cf. V. Berti, "Libri e biblioteche cristiane nell' Iraq dell' VIII secolo. Una testimonianza dell' epistolario del patriarca siro-orientale Timoteo I (727-823)," in C. D'Ancona (ed.), The Libraries of the Neoplatonists, Philosophia Antiqua 107 (Leiden, 2007), pp. 307-17.

${ }^{45}$ Pognon, Une version syriaque, p. XVII, 20 - p. XVIII, 1 (text), p. XX (translation); Brock, "Two Letters," p. 237 (translation) and pp. 242-44 (commentary); O. Braun, "Briefe des Katholikos Timotheos I," Oriens Christianus 2 (1902), pp. 7-11 (text and translation).

John W. Watt, "Commentary and Translation in Syriac Aristotelian Scholarship: Sergius to Baghdad," in: Journal for Late Antique Religion and Culture 4 (2010) 28-42; ISSN: 1754-517X; Website: http://www.cardiff.ac.uk/clarc/jlarc 
His translation of the Topics from Syriac to Arabic was commissioned by the caliph al-Mahdī, as we know from that same letter to Pethion, in which he also asks him to enquire at Mar Mattai "whether there is some commentary or scholia by anyone, whether in Syriac or not (puššāqa meddem 'aw skolāye d-'nāše ayk dabsury $\bar{a} y \bar{a}$ 'aw la ), to this book (which I was commissioned to translate, namely) the Topics, or to the Sophistical Refutations, or to the Rhetoric, or to the Poetics." He also remarks that Job the Chalcedonian had said to him that he had seen a few scholia on some chapters from it (the Topics). ${ }^{46}$ By grouping these four treatises together, Timothy's request clearly reflects the "four plus four" division of the Organon mentioned above, while his remark "whether Syriac or not", as also his mention of Job the Chalcedonian (presumably the patriarch of the Melkites mentioned in letter 48) indicates that he is interested in commentary in either Syriac or Greek. It would seem likely on the basis of this text that he knew the Rhetoric and Poetics in Syriac (as he clearly knew Athanasius' translation of the Topics, and presumably the same translator's version of the Sophistical Refutations), but it remains possible that he knew these last two only in Greek. ${ }^{47}$ It is not that surprising that he was struggling to find some commentary or scholia on these four works, for they were the least well covered by the Greek commentators, at least according to the extant evidence. Earlier than Timothy there are no extant Greek commentaries on the Rhetoric or Poetics, and on the Topics and Sophistical Refutations only those of Alexander. ${ }^{48}$ That on the Topics was known (in part) in the time of Yahyā ibn 'Adī and Ibn al-Nadīm, as were those (now lost) of Themistius and Ammonius, while that on the Sophistical Refutations was also known only in part and was rare. $^{49}$

We can therefore fully appreciate Timothy's difficulties in finding commentaries on these books, but we have not yet touched upon the most striking aspect of his remark. Timothy did not ask Pethion to look for any commentaries or scholia on the Categories, De Interpretatione, Prior Analytics, or Posterior Analytics, yet these are the most important books of the Organon. "Part Two" of the collection, Topics to Poetics - the books which only "additionally discuss things that are included in the method in another way" and merely "come after the art of logic"50 and following demonstration give instruction "about everything useful to it in any way" 51 - was considered far less important than "Part One" comprising Categories to Posterior Analytics/Apodeictics. It is true that in this letter Timothy is particularly concerned with the Topics in view of his remarks on its translation, and the Topics

${ }^{46}$ Pognon, Une version syriaque, p. XVI, 2 - p. XVII, 20 (text), pp. XVIII-XX (translation); Brock, "Two Letters," pp. 235-36 (translation) and pp. 240-242 (commentary); Braun, "Briefe des Katholikos Timotheos I," pp. 4-8 (text and translation).

${ }^{47}$ Cf. his mention of the Poetics in letter 19 (below, n. 56).

${ }^{48}$ Ed. M. Wallies, CAG II 2 and 3 (Berlin, 1891 and 1898). The latter is possibly pseudonymous. There is a graphic portrayal of the situation in the table of C. D'Ancona Costa, "Commenting on Aristotle: From Late Antiquity to the Arab Aristotelianism," in Geerlings and Schulze, Der Kommentar in Antike und Mittelalter, pp. 201-51, at p. 250.

${ }^{49}$ G. Flügel, Kitâb al-Fihrist (Leipzig, 1871), p. 249, 15-29. Cf. F. E. Peters, Aristoteles Arabus, Monographs on Mediterranean Antiquity (Leiden, 1968), pp. 20-22 (Topics), 23-26 (Sophistical Refutations).

${ }^{50}$ Ammonius, in Cat. p. 5, 22-23 and 29.

${ }^{51}$ Sergius, cf. above, n. 31.

John W. Watt, "Commentary and Translation in Syriac Aristotelian Scholarship: Sergius to Baghdad," in: Journal for Late Antique Religion and Culture 4 (2010) 28-42; ISSN: 1754-517X; Website: http://www.cardiff.ac.uk/clarc/jlarc 
belongs in "Part Two", but that does not in itself explain why he was keen to locate a commentary on the other three treatises. That can only be explained by a wish to find whatever he could on the whole Organon. However, if he had had any difficulty in finding commentaries on the books of "Part One", he would surely also have put in a word to Pethion to look out for them. That he did not do so strongly suggests that he did in fact have commentaries or scholia available to him on the first four books, "either in Syriac or not" (i.e. in Syriac or Greek).

Unlike "Part Two" of the Organon, there could well have been numerous commentaries available to Timothy on "Part I". In Greek, on the Categories we know of those by Porphyry, Dexippus, Ammonius, Philoponus, Simplicius, Olympiodorus and Elias; on De Interpretatione those by Ammonius and Stephanus; on the Prior Analytics those by Alexander, Themistius, Ammonius, Philoponus and Elias; and on the Posterior Analytics those by Alexander, Themistius, and Philoponus. ${ }^{52}$ At a later date Ibn al-Nadīm also mentions on the Categories Theophrastus, Allinus, Themistius, Iamblichus or Alexander, and Stephanus; and on De Interpretatione Theophrastus, Porphyry, Iamblichus, Philoponus and Stephanus. ${ }^{53}$ In Syriac we know of Sergius and George on the Categories; Paul the Persian, Probus and George on De Interpretatione; and Probus and George on the Prior Analytics (Probus to I 7); and in addition to these there are various scholia, letters, and discourses on individual matters. ${ }^{54}$ In letter 19 to Sergius Timothy asks Sergius to send a memorandum of the books in the monastery of Mar Zina, where there might be something of which he is unaware, and perhaps Sergius will find among the books there "the two treatises on poets, ${ }^{55}$ for I have one, or perhaps you will find among them the commentary ( $p u s ̌ s \bar{s} q \bar{a}$ ) of Olympiodorus on the books of the logic, or of Stephanus or of Sergius or of Alexander ..."

Whether Timothy had some of the commentaries of these authors and was looking for further ones, or whether he only knew about them from others, we cannot tell from this text. Nor can we tell whether he thought Syriac translations existed of commentaries by Olympiodorus, Stephanus, or Alexander, given his request to Pethion (in letter 43) for some commentary or scholia "in Syriac or not". However, it is striking that he places Sergius along with the three Greek commentators. What is clear is that he was interested in commentaries on the Organon, ${ }^{57}$ and given his search for those on the four treatises of "Part Two", it is very probable that he had available to him some on all four of "Part One".

The commission given by al-Mahdi to Timothy for a translation of the Topics into Arabic assuredly belongs to the Graeco-Arabic translation movement possibly

\footnotetext{
${ }^{52}$ For the details of the editions, cf. R. Goulet (ed.), Dictionnaire des philosophes antiques: Supplément (Paris, 2003), pp. 113-17.

${ }^{53}$ Flügel, Kitâb al-Fihrist, p. 248, 20-28 (Categories) and p. 249, 1-5 (De Interpretatione). Cf. Peters, Aristoteles Arabus, pp. 7-9 (Categories) and 12-13 (De Interpretatione); D'Ancona Costa, "Commenting on Aristotle," pp. 234-37.

${ }^{54}$ Cf. Brock, "The Syriac Commentary Tradition," pp. 12-14.

${ }^{55}$ Undoubtedly the two Books of Aristotle's Poetics. Cf. above, n. 47, and Berti, "Libri e biblioteche," pp. 312-15.

${ }^{56}$ Braun, Timothei Patriarchae I: Epistulae, p. 129 (text), p. 86 (version). Cf. Berti, "Libri e biblioteche," pp. 310-12, 315-16.

${ }^{57}$ And would have liked to find Book Two of Aristotle's Poetics! Timothy was also (in letter 43 ) anxious to find works by Nemesius and "someone of the Platonic school" (cf. above, n. 45).

John W. Watt, "Commentary and Translation in Syriac Aristotelian Scholarship: Sergius to Baghdad," in: Journal for Late Antique Religion and Culture 4 (2010) 28-42; ISSN: 1754-517X; Website: http://www.cardiff.ac.uk/clarc/jlarc
} 
"generated and sustained for a very long time by needs and tendencies in the nascent "Abbāsid society," do not. ${ }^{59}$ It was not in Baghdad (where he resided) that Timothy looked for further texts of Aristotle and his commentators, but in the libraries of monasteries such as Mar Mattai and Mar Zina, and those from whom he sought information were not courtiers to the caliph, secretaries, or physicians (although he moved among such), but a former teacher and fellow student from the monastic school at Bashosh. ${ }^{60}$ The Aristotelian culture of Timothy and his clerical associates was that of the GraecoSyriac movement of commentary and translation, which began with Sergius and continued through the Hellenists of the Syriac monastic schools, from where it eventually reached Baghdad. Even if the Graeco-Arabic translation movement as a whole started before al-Mahdī, there is no evidence to support the vague statement of al-Mas'ūdī (d. 956) that books by Aristotle 'on logic and other subjects' were translated into Arabic by order of the caliph al-Mansūr (754-775). ${ }^{61}$ Not until the ninth century was it possible for Arab readers to access much of the Organon and

${ }^{58}$ D. Gutas, Greek Thought, Arabic Culture. The Graeco-Arabic Translation Movement in Baghdad and Early 'Abbāsid Society $\left(2^{\text {nd }}-4^{\text {th }} / 8^{\text {th }}-10^{\text {th }}\right.$ centuries) (London-New York, 1998), p. 2. A different suggestion for the upsurge of translation activity in early Abbasid times is offered by G. Saliba, Islamic Science and the Making of the European Renaissance (Cambridge, MA, 2007), pp. 58-64. The observation of Saliba on astronomical and other texts of natural science, that Syriac scholars of late antique and Umayyad times only translated elementary works, while still retaining the capacity to read the more advanced Greek writings in the original (cf. also p. 8), is similar in some respects to the point about Aristotelian logic argued in this paper, namely, that translations were designed for the benefit of those less intellectually able - in the case of logic, those who could not read Aristotle in the original. Saliba attributes the change in the field of natural science to the Arabization of the civil service. In philosophy the change would seem to be more likely due to the diminishing knowledge of Greek among those interested in the subject.

${ }^{59}$ On Graeco-Syriac Aristotelianism and the commission for an Arabic version of the Topics, see my "Syriac Translators and Greek Philosophy in Early Abbasid Iraq," Journal of the Canadian Society for Syriac Studies 4 (2004), pp. 15-26, esp. pp. 17-19, 22-24; reprinted in my Rhetoric and Philosophy from Greek into Syriac (Farnham, 2010), chapter XIII.

${ }^{60}$ To emphasise the point that Timothy's interest in logic can hardly be assumed to derive from Arabic sources, it may be noted that we have no evidence of him looking for the logic compendium of Ibn al-Muqaffa'. As in letter 43, where in addition to philosophical works he also expresses interest in works of church fathers (Gregory and Dionysius), so here in letter 19 he also expresses the hope that Sergius might find "the ecclesiastical books of Ambrose, of Amphilocius against Apollinaris, or of the great Eustathius, or of Flavian, or of another," as also "the disputation of the great Athanasius against the Arians."

${ }^{61}$ Gutas, Greek Thought, Arabic Culture, p. 30 (Arabic in B. de Maynard, P. de Courteille, C. Pellat (eds), Les Prairies d'or, V [Beirut, 1974], p. 211, §3446, 11. 6-8). If "books by Aristotle on logic" had indeed been translated under order from al-Manșū, it is hardly likely that his successor (al-Mahdī) would have wanted a translation of the Topics from Timothy. Al-Mas'ūdī's statement may be an allusion to the logic compendium of Ibn al-Muqaffa' (d. 757), which is not "an early attempt ... to translate the Persian texts on logic" (thus Saliba, Islamic Science, p. 74, citing [n. 5] al-Qifțî), but an epitome of (Greek) logic based on the Syriac epitome tradition, dealing with the Organon up to Prior Analytics I 7; cf. H. Hugonnard-Roche, "L'intermédiaire syriaque dans la transmission de la philosophie grecque à l'arabe: Le cas de l'Organon d'Aristote,' Arabic Sciences and Philosophy 1 (1991), pp. 187-209, at pp. 203-204. The assertion of al-Mas 'ūdī immediately before this, that Kalīla wa-Dimna was among the books al-Manșūr had translated, might be held to lend some support to this suggestion, since Ibn al-Muqaffa' was in fact the translator of that work, although this was not mentioned by al-Mas' ${ }^{\mathrm{u}} \mathrm{d} \overline{\mathrm{i}}$.

John W. Watt, "Commentary and Translation in Syriac Aristotelian Scholarship: Sergius to Baghdad," in: Journal for Late Antique Religion and Culture 4 (2010) 28-42; ISSN: 1754-517X; Website: http://www.cardiff.ac.uk/clarc/jlarc 
its Greek commentators, and for the Posterior Analytics, the capstone of the Alexandrian scheme, they had to wait until its translation from the Syriac of Ishāa by Abū Bišr Mattā in the tenth. The Syriac and Arabic translations of the Abbasid era were not intended to be read alongside the Greek or to give an exact insight into the Greek wording. Hunayn himself recognised that a translation had to be judged in the light of its intended user(s), ${ }^{62}$ and a failure correctly to identify those of Athanasius' mirror translations may have been the cause of the harsh judgement on them by Ibn Suwār, who did not know Greek. ${ }^{63}$ The Syro-Arabic Baghdad Aristotelians of the school of Abū Bišr Mattā certainly belonged within the wider orbit of the Abbasid translation movement, but in their emphasis on the central importance of the logic of Aristotle and their employment of the translations and commentaries used in the Syriac monastic schools, ${ }^{64}$ they were also, although they did not know Greek, the heirs of the Graeco-Syriac Aristotelianism inaugurated by Sergius. ${ }^{65}$ If in their imaginary history of a school's migration al-Fārābī and alMas $^{6} \bar{u} d \overline{1}$ had wished to name locations which in reality contributed to the migration of Aristotelian logic "from Alexandria to Baghdad", rather than Antioch, Harran, and Marw they might have been nearer the mark had they mentioned Seleucia-onOrontes, Qenneshre, and Syriac monastic schools and libraries in the region of Mosul. $^{66}$

${ }^{62}$ Cf. G. Bergsträsser, Hunain ibn Ishāq über die syrischen und arabischen Galen-Übersetzungen (Leipzig, 1925), p. 2, 20-23 (Arabic), p. 2 (trans.). Cf. Gutas, Greek Thought, Arabic Culture, p. 140. Gutas's assumption (p. 141) that "such expert knowledge of Greek and capacity for translation acquired by Hunayn was not something that was routinely available in the Christian monasteries where presumably most of these translators were educated" may well be correct for the Abbasid period. But for the pre-Abbasid period of Greek-to-Syriac translations in the area east of Antioch, especially in monasteries such as Qenneshre with strong Greek connections, the opposite is likely to have been the case, if not "routinely", at least among those who undertook to make translations.

${ }^{63}$ Cf. Georr, Les Catégories d'Aristote, pp. 198-199; R. Walzer, Greek into Arabic (Oxford, 1962), p. 83. Possibly the desire for a translation with a more natural Syriac idiom, rather than a mirror translation, was a reason for Theophilus of Edessa's Syriac versions of the Prior Analytics and Sophistical Refutations, to which Ibn Suwār apparently did not take objection as he did to those of Athanasius. While the Baghdad Aristotelians did not know Greek, the feature important to the readers of the Qenneshre translations was exactly "the physical form (i.e., the precise and unique concatenation of words) given to it by its author," i.e., Aristotle (cf. Gutas, Greek Thought, Arabic Culture, pp. 140-41). The Arabic renderings in the Baghdad Organon of the Syriac versions referred to in its marginalia are not always flawless; cf. Hugonnard-Roche, La logique, pp. 33-35.

${ }^{64}$ The Baghdad Arabic Organon quotes translations of Athanasius and Jacob. Cf. HugonnardRoche, La logique, pp. 33-35 (Jacob and the Categories); Walzer, Greek into Arabic, pp. 85-88 (Athanasius and the Prior Analytics), p. 99 (Athanasius and the Topics), pp. 81-82 (Athanasius and the Sophistical Refutations); Watt, "The Syriac Organon," pp. 708-10.

${ }^{65}$ More details on the curriculum of Mattā's school and its connections with earlier Syriac Aristotelianism in my "From Sergius to Mattā."

${ }^{66}$ The background to the likely passage of Aristotelian scholarship from West to East Syrians through contacts in the region of Mosul has been greatly illuminated by V. Berti, Vita e studi di Timoteo I, patriarca cristiano di Baghdad (Paris-Leuven, 2009).

John W. Watt, "Commentary and Translation in Syriac Aristotelian Scholarship: Sergius to Baghdad," in: Journal for Late Antique Religion and Culture 4 (2010) 28-42; ISSN: 1754-517X; Website: http://www.cardiff.ac.uk/clarc/jlarc 